\title{
Effect of Audit Committee characteristics on Audit Quality: A Critical Literature Review
}

\author{
Alaallah A. M. Sharhan', Chandan Bora ${ }^{2}$ \\ ${ }^{1}$ Teaching Assistant, Faculty of Administrative Sciences, Thamar University, Yemen \\ ${ }^{2}$ Assistant Professor, Gondwana University, Gadchiroli, Maharashtra, India
}

\begin{tabular}{l} 
Article Info \\
\hline Article history: \\
Received: 15 July 2020 \\
Revised: 26 July 2020 \\
Accepted: 10 August 2020 \\
\hline Keywords: \\
Audit Committee, \\
Audit Committee Size, \\
Audit Committee Meeting, \\
Audit Committee Financial \\
Expertise, \\
Audit Committee Gender, \\
Audit Quality. \\
JEL: G20, H70, H83,M42. \\
Paper Type : \\
Review Article \\
\hline Corresponding Author: \\
Alaallah A. M. Sharhan \\
Email: \\
alaallahsharhan@ gmail.com
\end{tabular}

\begin{abstract}
Purpose: The aim of the paper is to present a critical literature review of the impact of audit committee characteristics (ACCs) on audit quality and to identify any research gaps in the field of audit quality. The aim is also to establish, if any, research gaps in the area of audit quality and to recommend any for potential research.

Approach/Methodology/Design: The methodology of this study is a review of literature on audit committee characteristics and audit quality. A number of research articles were analyzed.

Findings: The results of this review of literature revealed that audit committee size, audit committee meeting, and audit committee financial expertise have main effects on the audit quality in the public and private sectors.

Practical Implications: This review article gives an opportunity to auditors, management of audit offices and other stakeholders to better understand the pillars of audit quality, factors, and framework to reinforce the quality of the financial statements. This literature review contributes to better understanding of the role of the audit committee in financial statements. It provides researchers in the field with insights and new perspectives.

Originality/value: The paper identifies certain gaps and highlights the effect of effective audit committee on regulating and improving the finance department of any institution. The study also contributes to the operating organization of knowledge on the audit quality, dimensions of audit quality, and governing frameworks. It emphasizes the audit committee's effectiveness and also presents an opportunity to both researchers and the finance sector for potential future research.
\end{abstract}

\section{Introduction}

The perception of an audit is a concept that had received much attention from various sectors for many reasons. One justification for the increasing studies on audit is the lack of confidence of users in financial statements that are issued from organizations. Another important factor is accounting violations that are committed in the world at large in companies such as Enron and WorldCom (Rahmina and Agoes, 2014). Therefore, it is the responsibility of the staff of auditing to prepare and issue financial statements free from errors or irregularities.

International Auditing and Assurance Standards Board (IAASB, 2013) indicated that the recent financial terms have stressed fundamental importance of reliable, high-quality financial reporting in all economic sectors of the worlds, not least international capital markets, small 
companies, not-for-profit and government organizations and it underlined the urgent necessity, in the public interest, for continuous improvement towards audit quality. This study of literature on audit quality, and audit committee characteristics is an attempt to highlight the major fallouts and gaps in the finance research. Several aspects of audit related topics are discussed. The imperative behind this literature review is that today's organizational structure demands that financial information be timely ready and reliable. The aim is to give external auditors and users the confidence that the information provided can be trusted. Hence, this review is an attempt to highlight the most important aspects related to auditing.

\section{Literature Review}

\section{Audit Committee}

An audit committee (AC) is an advisory body elected by the board and to discharge their role in financial reporting, disclosure, appraisal of internal control system, and mitigate risk management (Asiriuwa et al., 2018; Tušek, 2015; Choi et al., 2014). It is composed of members from asymmetry backgrounds about age, gender, and education (Okiro et al., 2018). Above all, Audit Committee is deemed one out of the numerous mechanisms for corporate governance (Asiriuwa et al., 2018). Meanwhile, the audit committee is the link between both internal audit (Tušek, 2015) and external audit, therefore, creating a social relation between audit committees and external auditors leads to a decline in audit quality (He et al., 2017). Consequently, it makes great contributions in accounting and financial reporting, rule commitment, also risk management and in organization's internal control (Lekka, 2019).

In addition, the audit committee is a subsidiary committee established by the governing council mandating audit arrangements, conducting a regular examination and considering the financial statement. Accordingly, this committee strengthens the capacity of the council to fulfil its legal responsibilities and ensures the reliability and objectivity of financial reports (Isa \& Farouk, 2018). Besides, the board, shareholders, stakeholders, and all users must possess financial statements to make their managerial and economic decisions. Therefore, the audit committee plays an essential role in review financial statements before to present to the board (Hundal, 2019).

According to Malihi et al., (2012), the audit committee is of organizational structure which delegates it to play and oblige its overseeing function on the management, internal auditor, and independent auditors. Additionally, audit committees contribute to the financial reporting process (Islam et al., 2010) by supervising the managers inclined to manipulative earnings, increase the audit quality and decrease the interview of the board of directors (Isa \& Farouk, 2018). Furthermore, audit committees play a significant role as a linked between the firm's management and external auditors about accounting issues (Islam et al., 2010).

In other studies (Sultana et al., 2015; Oussii \& Boulila Taktak, 2018) contended that the role of audit committee characteristics as independence, financial expertise, size, diligence, and authority in improving the timeliness of financial reporting. Furthermore, audit committee characteristics represented by independence, size, financial expertise, and gender diversity have a positive and 
significant impact on a company's social responsibility detection (Barzegar et al., 2019; Appuhami\&Tashakor, 2017). Not only but also, in other studies (Mohammed, 2018; Zraiq and Fadzil, 2018), it is found that the frequencies of the audit committee had a positive relationship with firm performance. Otherwise, (Barka\& Legendre, 2017; Alqatamin, 2018; Rahman et al., 2018) revealed that the audit committee meetings had a negative association with firm performance. A study from Nigeria by (Isa \& Farouk, 2018) found out that the audit committee has a negative significant effect on earnings management of few and greater leveraged banks.

\section{Audit Committee Size and Audit Quality}

Although previous studies tackled the size of an audit committee, so the numbers of the person who join up the committee are unfixed. However, (Asiriuwa et al., 2018; Suryanto et al., 2017; Khudhair et al., 2019) in a related study revealed that audit committee size had a positive correlation toward audit quality. On the other hand, the Security Exchange and Board of India (SEBI's) Clause 49, "A qualified and independent AC shall set up. Section 359(3) of the CAMA (2004) stated that audit committee membersin public companies in Nigeria shall not exceed fivein number. Two-thirds of the members of AC shall be independent directors." The audit committee is a component of corporate governance and enhances auditing quality.

Furthermore, (Hamdan et al., 2013) at Amman Stock Exchange Market in the financial sector had examined the relationship between audit committee size on financial performance, operating performance and stock performance, listed. It concluded that audit committee characteristics impacted financial and stock performance. It did not influence operating performance. On a sample of fifteen Deposit Money Banks and the annual reports and accounts of the banks for the period 2008-2015 in Nigeria, (Isa \& Farouk, 2018) resulted audit committee size thereof has a significant effect on earnings management.

The audit committee is part and parcel of any organization, contributing to financial reporting and effective financing management. Therefore, previous literature reveals that audit committee characteristics affect financial reporting (Oussii \& Boulila Taktak, 2018; Mwangi, 2018; Lekka, 2019; Endrawes et al., 2018). Accordingly, increasing the member of an audit committee means that the financial statement comparability is higher (Endrawes et al., 2018).

Through recent years, paying attention to intellectual capital and the role of audit committees have widened extensively in terms of their role in improving intellectual capital. As an example, Buallay (2018) underscored that audit committee size positively affects the capital employed efficiency which is a component of intellectual capital in banks at Gulf Cooperation Council countries(GCC) namely Bahrain, Kuwait, Oman, Qatar, Saudi, and UAE. On the contrary, the size of the audit committee insignificantly impacts the disclosure of intellectual capital (Isnalita \& Romadhon, 2018).

\section{Audit committee meeting and audit quality}

The audit committee meeting is a count of sessions to consult and debate the accounting and auditing process in an organization. As a result, it may hold the meeting either per quarter, half- 
yearly or four times per year. Undoubtedly, the size of an audit committee is increasing; the frequency of meetings with them is decreasing. This is due to the difficulty in communicating with audit committee members. Waweru (2018) showed that the means of several Audit Committee meetings were 3.5. In his study, he listed companies in East Africa which reflected compliance with the corporate governance code in Kenya and Tanzania. Yet, corporate governance disclosure level is affected, but insignificantly, as a consequence of the frequency of meetings audit committee (Ebirien et al., 2018). Although the organization aims at the quality of financial reports, the managers manipulate the earnings for the sake of their interests. Therefore, audit committees alleviate and curtail these actions; therein proves (Isa \& Farouk, 2018; Zgarni et al., 2016) that the audit committee meeting has a significant impact on earnings management.

Undeniably, the audit committee plays a pivotal role in a firm asset either tangible or intangible. In connection to this, Buallay (2018) tackled audit committee characteristics and disclosed that the meetings of the audit committee impact the intellectual capital in banks, giving GCC as an example. The study found out that audit committee frequency of meeting has a positive significant association with human capital efficiency, structural capital efficiency, and relational capital efficiency. Even though, the role of the audit committee covers not only the policies of an organization but also environmental policies such as social contracts. Moreover, the frequency audit committee meeting positively affected environmental performance (Chariri et al., 2017). In South Africa, the Johannesburg Stock Exchange has since 2014 demand that all firms registered on its exchange provide integrated reports that cover sustainability information. In other words, (Chariri \& Januarti, 2017) carry out this study in Johannesburg Stock Exchange, they found that the rate of audit committee meetings positively impacts integrated reports.

Consequently, Salawu et al. (2017) examined the relationship between audit committee characteristics and audit quality. Based on correlation and multiple regression, the results inferred that audit committee expertise and the meeting had insignificant effects on audit quality of listed consumer-goods companies in Nigeria. Correspondingly, Ghafran \& O'Sullivan (2017) found that meeting frequency has a positive impact on audit quality, as a surrogate by the audit fee. Mwangi (2018) similarly investigated the effect of audit committee characteristics on the quality of financial reports in public secondary schools in Kenya. Consequently, the findings came out that the many audit committees meeting has a positive effect on the quality of financial reporting. Nevertheless, DeFond \& Zhang (2014) recommend that the researchers to use a variety of proxies from different dimensions in their research to gain the merit of their strengths and decline their weaknesses. The author addressed the exogenous variables to measure audit quality into four divisions namely material misstatements, auditor communication, financial reporting quality, and observation; whereas the endogenous variables into two categories-auditor features and auditorclient contracting attributes as audit fees (DeFond\& Zhang, 2014). Accordingly, most of the studies reviewed approve the positive effect of audit committee on audit quality.

\section{Audit Committee Financial Expertise and Audit Quality}

Previous research using the wide definition of financial expertise has provided mixed evidence about an association between financial expertise and other factors. They have focused on the effect ISSN: $2708-9320$ (Print)

Copyright (C) 2020, Journal of Advanced Research in Economics and Administrative Sciences (JAREAS), Under the license CC BY 4.0 
of audit committee financial experts (ACFE) on different factors, such as earnings management, analyst forecast accuracy, and audit quality. The Financial Reporting Council (FRC) (2012a) lay down that the Audit Committee should have adequate expertise, prescribing that "the board should satisfy itself that at least one member of the audit committee has recent and relevant financial experience". Consequently, the internal audit function (IAF) should emphasize the AC and top management that all organizational processes and systems are judiciously created to manage risk, and where the necessity to allow for adjustments to be initiated should they be required to reach this overall aim (Alzeban \& Sawan, 2015). In addition, Badolato et al., (2014),Wan Mohammad et al. (2016), and Alzoubi, (2019) found that audit committees with financial expertise (ACFE) are associated with a reduction of earnings management, a lower probability of engaging in risky tax planning (Robinson, 2012), and greater analyst earnings forecasts (Abernathy, 2013). In addition, Endrawes et al. (2018) segregate the audit committee expertise in the financial and audit field into three types namely non-expertise of audit committee members, less than half audit committee members, and either half or more audit committee members. The results revealed that half or more audit committee members have a positive relationship with financial statement comparability. However, Hidayah, Sukirman, \& Mahmud (2018) asserted that audit committee expertise has an insignificant relationship with audit committee frequency meetings. Likewise, audit committee expertise has a negative effect on human capital efficiency (Buallay, 2018).

Iyer et al. (2013) examined the characteristics and qualifications of an audit committee member in a particular financial expert. Furthermore, they used the board of directors (BOD) to appoint an audit committee financial expert. For instance, a prior experience in a management position, a prior experience as an independent board member, a prior professional relationship with any member of the management, a prior informal relationship with any member of the management, a senior management position, CPA, CMA, or CIA certification, auditing experience, and a prior audit committee experience. Despite having a lot of characteristics and qualifications, they inferred that an audit committee member with the financial expert thereof who is assigned by BOD has accounting certification and audit committee experience. Alzeban \& Sawan (2015) confirm the positive influence on the knowledge and experience of audit committee members in accounting, auditing and finance, and the perceptions of implementing internal audit recommendations.

Besides, Mwangi (2018), Bajra \& Čadež (2018), and Eyenubo et al. (2017) prove that audit committee members with the knowledge, accounting, auditing, and finance have positive effects with quality of financial reporting. Nevertheless, the audit committee is an indispensable prerequisite in firms, but not an adequate case for fostering quality financial reports (Bajra \&Čadež, 2018). However, AC expertise's has a negative and statistically insignificant effect in relation to the quality of financial reports in public secondary schools in Murang'a County (Mungai \& Muturi). Moreover, Islam et al. (2010) asserted that audit committees members charged with auditing and analyzing process, and evaluating financial statements, those who have both professional qualifications and experience. 
In the USA, Mustafa \& Ben Youssef (2010) examined the relationship between the ACFE and the occurrence of misappropriation of assets in publicly held companies. Moreover, the researchers have segregated financial expertise between accounting and non-accounting financial expertise. Therefore, the findings revealed that the percentage of financial expert members and the percentage of independent members in the $\mathrm{AC}$ were inversely associated with the probability of misappropriation of assets. Also, an examination of AC independence and financial expertise pointed out that the proportion of independent AC members with financial expertise was negatively and significantly linked to the occurrence of misappropriation of assets, whilst the percentage of independent AC members with non-financial expertise insignificantly linked to the occurrence of misappropriation of assets. Both males and females perform their duties as members of BOD and AC. Therefore, Xiang \& Qin (2017) derived the female accounting expertise had an insignificant effect on quality external audit demand. Furthermore, women's financial experts on the AC are significantly associated with low earnings management (Zalata et al., 2018; Zgarni et al., 2016).

Although, previous studies have also shown the difficulties involved in measuring audit quality, however, the studies are being undertaken in the UK and Australia measured audit quality by audit fees (Ghafran\& O'Sullivan, 2017; Sultana et al., 2019). Ghafran \& O'Sullivan, (2017) use audit fees as a proxy of audit quality and influence audit committee expertise on audit fees. The sample of the study was the Financial Times-Stock Exchange (FTSE) 350 firms and neglected the financial firms in the UK. The researchers have separated financial expertise between accounting and non-accounting, financial expertise. Even though the results showed that proportion accounting, financial expertise was a negative impact on audit fees, non-accounting, financial expertise has a positive impact and significant on audit fees. Moreover, when they isolated the companies into FTSE250 and FTSE 150, they found that they restricted the impacting on FTSE250. Whereas Sultana et al. (2019) investigated audit committee characteristics namely audit committee member period, age and multiple-directorships. The results concluded that these characteristics had a positive relationship with audit fees as a surrogate audit quality.

\section{Audit Committee Gender and Audit Quality}

An assortment of employers either men or women are cohering members; therefore, females are an indispensable prerequisite in an organization. For instance, the countries of Australia, Canada, and the United Kingdom deemed gender diversity as a component of corporate governance the finest practices (ASX Corporate Governance Council, 2010; Financial Reporting Council, 2014). In the occurrence of a female member in the audit committee, the results of earnings management are lower (Zalata et al., 2018). Thiruvadi \& Huang (2011), found also no relationship between discretionary accruals as a replacement of earnings management and female of an audit committee. Other studies have also explored the association between audit committee gender diversity and audit fees. For example, Aldamen et al. (2018) Ittonen et al. (2010), both of them conducted their studies on many non-financial institutions. They deduced that females had a positive relationship with audit fees paid for external auditors. 
Velte (2018) examined the association between female audit committees in UK firms and key audit matters (KAM) disclosures in the audit report. Thus, the results revealed that the percentage of females had a positive impact on auditors' disclosures key audit matters. Moreover, a study from Kenya by Mwangi (2018) showed that audit committee diversity had a negative and significant relationship with the quality of financial reporting measured by the ratio of queried transactions to an annual budget. Mungai \& Muturi similarly investigated the effect of audit committee characteristics on the quality of financial reports in public secondary schools in Kenya. The findings concluded that the diversity of audit committees has a negative and statistically insignificant association with financial reports of public secondary schools within the Murang'a County.

Previous studies have concentrated on the role of gender of the audit committee on the audit committee meeting frequency. As an example, using data listed on stock exchange of non-financial firms in Indonesia in 2012, Hidayah, Sukirman, \& Mahmud (2018) found that the presence of women audit committees has no effect the audit committee meeting frequency.

\section{Audit Quality}

The current paper perhaps begins with the more specific notion of quality before addressing the concept of audit quality. Furthermore, there were many differing opinions on the concept of quality, for instance, but not limited either in productive sectors or financial institutions. Krisnanto \& Novianti, (2019) and Delima et al. (2019) defined 'quality' as a standard of how just the level of service is presented and able to satisfy customer prediction. Moreover, all interested in academics, researchers and professionals concentrated on auditing, essentially the quality of audit as a result of the collapse of international companies and the lack of confidence of the beneficiaries in truth and fairness of financial statements. DeAngelo (1981) tackled the definition of audit quality from two aspects; first; the auditor evaluates the structure of the client's and finds out the drawbacks in financial statementsas an auditor; second, to make known or disclose these matters vague and inaccuracy. The audit quality is depending on the competence and independence of the auditor (Khani and Noroozian, 2018). According to Nurdiono and Gamayuni (2018), audit quality is increasing provided that the presence of auditor's competency betterment that is obtained over with the longer assignment period of an auditor. Furthermore, the International Auditing and Assurance Standards Board (IAASB, 2014; Sulaiman and Turley, 2011) asserts that audit quality is a framework including five drivers namely: firstly, input (value, ethics, and characteristics of auditors), secondly, process (quality control procedures), third, output (reports and financial statements), then, key interactions within the financial reporting supply chain (argument between the auditor and the AC), and finally contextual factors (laws and regulations and corporate governance).

\section{Methodology and Procedures}

ISSN: $2708-9320$ (Print)

Copyright (C) 2020, Journal of Advanced Research in Economics and Administrative Sciences (JAREAS), Under the license CC BY 4.0 
The paper is a literature review. It follows a systematic analysis of research in audit quality in general and the effect of audit characteristics on auditing specifically. For this purpose, several published research articles as well as books were reviewed and critically analyzed. Certain questions were posed in order to guide the researchers throughout the review process. The study reviews the impact of the audit committee characteristics on audit quality in banks and the following question were taken into account: how does the audit committee affect audit quality in the banks? How do audit committee characteristics contribute to the audit quality? And, what are the research gaps in the field of audit quality?

\section{Results and Discussion}

The results of both the characteristics of the audit committee and audit quality reveal that there is a need for further thorough studies on the field. Research on the relationship between audit quality, audit committee characteristics and auditors in both the public and private sectors has been continuing with comprehensive results on the real nature of the audit quality framework, pillars of audit quality and concept of audit quality. The AC characteristics have a major impact on audit quality in the public and private sectors. The qualification of the team of the AC is reflected in their knowledge, competence, and expertise. The size of the audit committee and AC's frequency of meetings are believed to enhance the financial reporting quality, leading to more audit quality. The informal links the committee has with audit stakeholders including both internal and external auditors, also top management improves the quality of audits in the public and private sectors.

Audit inputs especially incentives and motivation, professional scepticism between auditors, the knowledge and expertise of the audit members, audit partners, director of the audit along with the training and experience over years of service, including company pressures may affect audit quality. Audit findings reflect upon the nature of audit inputs which have been addressed. Audit reports should take facts and underpin full evidence with audit documentation such as audit work papers. The regulatory reviews of audit offices by regulators show insufficiencies underlined on audit quality procedures. The contextual framework under which audit is fulfilled may impact audit quality. The audit partner incentives and other audit staff wages may affect audit quality.

\section{Conclusion and Suggestion}

The present paper presented a literature review of work on audit quality. The paper investigated the possible effects of audit characteristics on improving the quality of auditing. Several research studies and books were selected as sources for this paper, and a systematic analysis was conducted. The findings reveal that there is a dynamic relationship between audit quality, audit committee characteristics and auditors in both the public and private sectors. The review indicates that the Audit Committee characteristics have main effect on the audit quality in the public and private sectors. In addition, it pointed that the qualification of the team of the Audit Committee should only be judged by their their knowledge, competence, and expertise in performing their duties. The size of the audit committee and AC's frequency of meetings are believed to enhance the financial reporting quality, leading to more audit quality. 
The empirical literature reviewed shows that the size of AC, AC's frequency of meetings and expertise of members improve AC effectiveness which is a controversial issue in the organizations. The review further doe not link AC characteristics with audit quality, and it emphasizes that there is dearth of research done on critical audit attributes having greater effect on audit quality. There is a need to conduct research on the effects of audit committee characteristics on audit quality in banks. In addition, further research can be conducted to find the relationship between audit quality framework, audit quality pillars and audit quality which will support audit committees to found the key audit quality indicators as one of their performance indicators at the starting of each fiscal year. The study recommends a further examination of the effect of audit committee independence and gender on audit quality.

\section{Conflict of Interest}

The author of the article declares no conflict of interest.

\section{Funding}

This research study was not funded by any institution. The author conducted the study on his own expenses.

\section{References}

Abernathy, J. L., Herrmann, D., Kang, T., \& Krishnan, G. V. (2013). Audit committee financial expertise and properties of analyst earnings forecasts. Advances in Accounting, 29(1), 111.

Aldamen, H., Hollindale, J., \&Ziegelmayer, J. L. (2018). Female audit committee members and their influence on audit fees. Accounting \& Finance, 58(1), 57-89.

Alqatamin, R. M. (2018). Audit committee effectiveness and company performance: evidence from Jordan. Accounting and Finance Research, 7(2), 48.

Alzeban, A., \&Sawan, N. (2015). The impact of audit committee characteristics on the implementation of internal audit recommendations. Journal of International Accounting, Auditing and Taxation, 24, 61-71.

Alzoubi, E. S. S. (2019). Audit committee, internal audit function and earnings management: evidence from Jordan. Meditari Accountancy Research, 27(1), 72-90.

Appuhami, R., \&Tashakor, S. (2017). The impact of audit committee characteristics on CSR disclosure: An analysis of Australian firms. Australian Accounting Review, 27(4), 400420.

Asiriuwa, O., Aronmwan, E. J., Uwuigbe, U., \&Uwuigbe, O. R. (2018). Audit committee attributes and audit quality: a benchmark analysis. Business: Theory and Practice, 19, 3748.

Asiriuwa, O., Aronmwan, E. J., Uwuigbe, U., \&Uwuigbe, O. R. (2018). Audit committee attributes and audit quality: a benchmark analysis. Business: Theory and Practice, 19, 37-48.

ISSN: $2708-9320$ (Print)

Copyright (C) 2020, Journal of Advanced Research in Economics and Administrative Sciences (JAREAS), Under the license CC BY 4.0 
Badolato, P. G., Donelson, D. C., \&Ege, M. (2014). Audit committee financial expertise and earnings management: The role of status. Journal of Accounting and Economics, 58(2-3), 208-230.

Bajra, U., \&Čadež, S. (2018). Audit committees and financial reporting quality: The 8th EU Company Law Directive perspective. Economic Systems, 42(1), 151-163.

Barka, H. B., \& Legendre, F. (2017). Effect of the board of directors and the audit committee on firm performance: a panel data analysis. Journal of Management \& Governance, 21(3), 737-755.

Barzegar, G., Hasannataj, K. M., \& Malaki, D. (2019). An Investigation of the Audit Committee Characteristics Effects on Corporate Social Responsibility Disclosure.

Buallay, A. (2018). Audit committee characteristics: an empirical investigation of the contribution to intellectual capital efficiency. Measuring Business Excellence, 22(2), 183-200.

Chariri, A., \&Januarti, I. (2017). Audit committee characteristics and integrated reporting: Empirical study of companies listed on the johannesburg stock exchange. European Research Studies, 20(4B), 305-318.

Chariri, A., Januarti, I., \&Yuyetta, E. N. A. (2017). Firm Characteristics, Audit Committee, and Environmental Performance: Insights from Indonesian Companies. International Journal of Energy Economics and Policy, 7(6), 19-26.

Choi, Y. K., Han, S. H., \& Lee, S. (2014). Audit committees, corporate governance, and shareholder wealth: Evidence from Korea. Journal of Accounting and Public Policy, 33(5), 470-489.

Companies and Allied Matters Act, CAMA (2004) as amended. Abuja-Nigeria.

Council, A. C. G. (2010). Corporate governance principles and recommendations with 2010 amendments. Australian Securities Exchange, Sydney.

Council, F. R. (2012). Guidance on audit committees. London: FRC. Available at: http://www. frc. org. uk/getattachment/6ec23196-28ee-406e-8f56-89ab9d1dc06d/Guidance-on-AuditCommittees-September-2012. aspx.

Council, F. R. (2012). The UK corporate governance code. London, September.

Delima, A., Ashary, H. M., \& Usman, O. (2019). Influence of Service Quality, Product Quality, Price, Brand Image, and Promotion to Consumer Satisfaction Affecting on Consumer Loyalty (Online Shop). Product Quality, Price, Brand Image, and Promotion to Consumer Satisfaction Affecting on Consumer Loyalty (Online Shop)(January 1, 2019).

Ebirien, G. I., Chukwu, G. J., \&Ohaka, J. (2018). Audit Committee Characteristics and Corporate Governance Disclosure of Nigerian Deposit Money Banks. Asian Journal of Economics, Business and Accounting, 1-14.

Endrawes, M., Feng, Z., Lu, M., \& Shan, Y. (2018). Audit committee characteristics and financial statement comparability. Accounting \& Finance.

Eyenubo, S. A., Mohammed, M., \& Ali, M. (2017). Audit committee effectiveness of financial reporting quality in listed companies in Nigeria stock exchange.International Journal of Academic Research in Business and Social Sciences, 7(6), 487-505. 
Ghafran, C., \& O'Sullivan, N. (2017). The impact of audit committee expertise on audit quality: Evidence from UK audit fees. The British Accounting Review, 49(6), 578-593.

Hamdan, A. M., Sarea, A. M., \&Reyad, S. M. R. (2013). The impact of audit committee characteristics on the performance: Evidence from Jordan. International Management Review, 9(1), 32-42.

He, X., Pittman, J. A., Rui, O. M., \& Wu, D. (2017). Do social ties between external auditors and audit committee members affect audit quality? The Accounting Review, 92(5), 61-87.

Hidayah, R., Sukirman, A. W., \& Mahmud, A. (2018). The determinants of audit committee meeting frequency in Indonesia. The Social Sciences, 13(1), 53-56.

Hundal, S. (2019). Corporate boards and audit committees in India-The impact of independence and busyness of corporate boards and audit committees on firm performance and financial reporting quality. JYU dissertations.

IAASB. (2014). A Framework for Audit Quality: Key Elements that Create an Environment for Audit Quality.

Isa, M. A., \& Farouk, M. A. (2018). A study of the effect of diversity in the board and the audit committee composition on earnings management for low and high leveraged banks in Nigeria. Journal of Accounting, Finance and Auditing Studies, 4(1), 14-39.

Isa, M. A., \& Farouk, M. A. (2018). The Moderating Effect of Audit Committee on the Relationship between Board Diversity and Earnings Management of Banks in Nigeria. Iranian Journal of Accounting, Auditing \& Finance, 2(1).

Islam, M. Z., Islam, M. N., Bhattacharjee, S., \& Islam, A. (2010). Agency problem and the role of audit committee: Implications for corporate sector in Bangladesh. International journal of Economics and Finance, 2(3), 177-188.

Isnalita, N., \&Romadhon, F. (2018). The Effect of Company Characteristics and Corporate Governance on the Practices of Intellectual Capital Disclosure. International Research Journal of Business Studies, 11(3), 217-230.

Ittonen, K., Miettinen, J., \&Vähämaa, S. (2010). Does female representation on audit committees affect audit fees? Quarterly Journal of Finance and Accounting, 113-139.

Iyer, V. M., Bamber, E. M., \& Griffin, J. (2013). Characteristics of audit committee financial experts: an empirical study. Managerial Auditing Journal.

Khani, M. K., \&Noroozian, M. (2018). Analyzing the Effective Factors on Internal Audit Quality of Health Insurance Organization of Iran. International Journal of Academic Research in Accounting, Finance and Management Sciences, 8(1), 19-25.

Khudhair, D., Al-Zubaidi, F., \& Raji, A. (2019). The effect of board characteristics and audit committee characteristics on audit quality. Management Science Letters, 9(2), 271-282.

krisnanto, U., \&Novianti, R. (2019). Examining the relationships between service quality, corporate image, customer satisfaction, and customer loyalty for an indonesian bank. expert journal of business and management, 7(1).

Lekka, M. (2019). The impact of female representation in audit committees on earnings management: Some evidence from EU.

ISSN: $2708-9320$ (Print)

Copyright (c) 2020, Journal of Advanced Research in Economics and Administrative Sciences (JAREAS), Under the license CC BY 4.0 
Malihi, S. A., Mahdavikhou, M., \&Khotanlou, M. (2012). An Investigation into the relationship between audit committee and audit quality. Australian Journal of Basic and Applied Sciences, 6(10), 409-416.

Mohammed, A. M. (2018). The impact of audit committee characteristics on firm performance: Evidence from Jordan. Academy of Accounting and Financial Studies Journal.

Mohiuddin, M., \& Karbhari, Y. (2010). Audit committee effectiveness: A critical literature review. AIUB Journal of Business and Economics, 9(1), 97-125.

Mungai, K. G., \& Muturi, W. Effect of Audit Committee Characteristics on the Quality of Financial Reports in Public Secondary Schools in Kenya: The Case of Public Secondary Schools in Murang'a County.

Mustafa, S. T., \& Ben Youssef, N. (2010). Audit committee financial expertise and misappropriation of assets. Managerial Auditing Journal, 25(3), 208-225.

Mwangi, A. K. (2018). Effect of Audit Committee Characteristics on Quality of Financial Reporting among Non-Commercial State Corporations in Kenya. JKUAT.

Nurdiono, \&Gamayuni, R. R. (2018). The Effect of Internal Auditor Competency on Internal Audit Quality and Its Implication on the Accountability of Local Government. European Research Studies Journal, 21(4), 426-434.

Okiro, K., Samuel, A. J., Chege, E. N., Cheku, M. F., \&Bulilo, M. J. (2018). The Effect of Audit Committees on the Performance of County Governments in Kenya. African Development Finance Journal (ADFJ), 2(1).

Oussii, A. A., \&BoulilaTaktak, N. (2018). Audit committee effectiveness and financial reporting timeliness: The case of Tunisian listed companies. African Journal of Economic and Management Studies, 9(1), 34-55.

Rahman, M. M., Meah, M. R., \&Chaudhory, N. U. (2019). The Impact of Audit Characteristics on Firm Performance: An Empirical Study from an Emerging Economy. The Journal of Asian Finance, Economics and Business (JAFEB), 6(1), 59-69.

Rahmina, L. Y., \&Agoes, S. (2014). Influence of auditor independence, audit tenure, and audit fee on audit quality of members of capital market accountant forum in Indonesia. ProcediaSocial and Behavioral Sciences, 164, 324-331.

Robinson, J. R., Xue, Y., \& Zhang, M. H. (2012). Tax planning and financial expertise in the audit committee. Available at SSRN 2146003.

Salawu, O. M., Okpanachi, J. O., Yahaya, O. A., \&Dikki, C. A. (2017). Effects of audit committee expertise and meeting on audit quality of listed consumer-goods companies in Nigeria. European Journal of Accounting, Auditing and Finance Research, 5(10), 61-79.

Securities and Exchange Board of India, "Corporate Governance in Listed Corporations: Clause 49 of the Listing Agreement," 2004.

Sultana, N., Singh, H., \& Rahman, A. (2019). Experience of Audit Committee Members and Audit Quality. European Accounting Review, 1-29.

Sultana, N., Singh, H., \& Van der Zahn, J. L. M. (2015). Audit committee characteristics and audit report lag. International Journal of Auditing, 19(2), 72-87.

ISSN: $2708-9320$ (Print)

Copyright (C) 2020, Journal of Advanced Research in Economics and Administrative Sciences (JAREAS), Under the license CC BY 4.0 
Suryanto, T., Thalassinos, E., \&Thalassinos, I. (2017). Board Characteristics, Audit Committee and Audit Quality: The Case of Indonesia. International Journal of Economics \& Business Administration, 5(3), 47-57.

Thiruvadi, S., \& Huang, H.-W. (2011). Audit committee gender differences and earnings management. Gender in Management: An International Journal, 26(7), 483-498.

Tušek, B. (2015). The influence of the audit committee on the internal audit operations in the system of corporate governance-evidence from Croatia. Economic researchEkonomskaistraživanja, 28(1), 187-203.

United States. (2002). Sarbanes-Oxley Act of 2002: Conference report (to accompany H.R. 3763). Washington, D.C.: U.S. G.P.O..

Velte, P. (2018). Does gender diversity in the audit committee influence key audit matters' readability in the audit report? UK evidence. Corporate social responsibility and environmental management, 25(5), 748-755.

Wan Mohammad, W. M., Wasiuzzaman, S., \& Nik Salleh, N. M. Z. (2016). Board and audit committee effectiveness, ethnic diversification and earnings management: a study of the Malaysian manufacturing sector. Corporate Governance, 16(4), 726-746.

Waweru, N. (2018). Audit committee characteristics, board ethnic diversity and earnings management: evidence from Kenya and Tanzania. International Journal of Corporate Governance, 9(2), 149-174.

Xiang, R., \& Qin, M. (2017). Female Audit Committee Member's Characteristics and High Quality External Audit Demand. Paper presented at the Proceedings of the Tenth International Conference on Management Science and Engineering Management.

Zalata, A. M., Tauringana, V., \&Tingbani, I. (2018). Audit committee financial expertise, gender, and earnings management: Does gender of the financial expert matter? International review of financial analysis, 55, 170-183.

Zgarni, I., Hlioui, K., \&Zehri, F. (2016). Effective audit committee, audit quality and earnings management: Evidence from Tunisia. Journal of Accounting in Emerging Economies, 6(2), 138-155.

Zraiq, M., \&Fadzil, F. (2018). The impact of audit committee characteristics on firm performance: Evidence from Jordan. Sch J Appl Sci Res, 1, 39-42. 